\title{
SEMANTIC PECULIARITIES OF HEADINGS IN STEPHEN KING LITERARY WORKS
}

\section{Tetiana Borysova ${ }^{1}$}

DOI: https://doi.org/10.30525/978-9934-588-15-0-106

Abstract. The purpose of the article is to describe the stylistic and pragmatic potential of paratextual elements in the fiction works by a modern American writer Stephen King. Methodology. The descriptive and comparative methods, as well as of structural-semantic and contextual analysis, allowed us to discover basic means of the paratextual elements conceptualization and define their functions. The survey is based on the material from more than 620 literary texts by Stephen King and their translations into Ukrainian language. Practical implications. The article presents a brief contemplated survey of the basic studies in the theory of the paratext, different views in this sphere in domestic and foreign linguistics; the main pragmatic and stylistic functions implemented of such important in its influence on the reader paratextual element as a title are identified. The study deals with the analysis of the composition and plot construction of Stephen King's literary works and publicist essays, which resulted in a number of features specific to the author's writing techniques. Value / originality. The investigation shows that the paratext in Stephen King's works plays an important structural and meaningful role in artistic and semantic comprehension of the literary discourse under analysis. The paratextual elements in stories are closely associated with the further text and serve as a clearly deliberate projection of the plot and a reader's guide into this content. Conclusions. It was determined that the title is one of the main paratextual elements that carries factual, conceptual and subtextual information in the literary works under analysis, as well as introduces a significant layer of cultural information into the artistic space. Being closely related to the subtext and directly to the text of a novel or a story, the title promotes a coherent reading of the literary work since headings bear an exact semantic projection of the artistic

${ }^{1}$ Candidate of Philological Sciences,

Associate Professor at Department of Foreign Languages,

Kherson State University, Ukraine 
content of the corresponding text and act as a link between the chapters in the novel or plot lines in a story. Besides, the communicative function of the title of a literary work, as an element of a dialogue between the author and the reader has been defined.

\section{Introduction}

Our work is devoted to the consideration of the relationship between paratextual elements (the title in particular) and the text of the literary works by Stephen King. An attempt has been made to review how the paratext, especially the pretext interprets the following text and prepares the reader for its perception. The importance of the information contained in the paratext, is determined by its ability to disclose the overall meaningful plan of the work. At the same time, the available general background knowledge of the writer and readers is updated, relying on which, the author, through the purposeful selection of language units, intentionally influences the reader. This article is written in line with the scientific work on the theory of speech impact on the language community through written texts. Due to the fact that any text has a certain structure and specific communicative-pragmatic content, in our paper we have made an attempt to study not the text itself in its pure form, but the textual periphery, which has a pragmatic meaning. The study refers to the concept of "paratext," which appeared relatively recently in literary criticism and textology. Thus, the relevance of the research is substantiated by a small amount of study of paratext in comparison with the main texts of the literary works and their special role in the interpretation of the author's intention. The goal is to identify the communicative potential of a paratextual element and the ways of its language implementation, as well as to establish its functional significance on the material of Stephen King's stories, novels and essays. The descriptive method, as well as of structural-semantic and contextual analysis, allowed us to discover basic means of the paratextual elements conceptualization and define their functions. The comparative method has also been used in the investigation of the original and the translated text.

\section{Analysis of recent research and publications}

In modern literary studies the interest in elements that do not fully belong to the text of a literary work but, nevertheless constitute a whole, arose after the publication in 1987 of the work of the famous French researcher Gerard 
Genette "Seuils". The author understands by paratext some elements of a work of art that only partially belong to the text of the work itself, but at the same time constitute a single whole with it, which is called a book. According to the researcher, paratext is what allows a text to become a book [11]. His ideas were continued by colleagues I. de Jong, C. Ashley, E. Tribble, P. Burke, S. Brown and others. G. Genette subdivides all paratextual elements into two broad categories: peritext and epitext. To the peritext such elements as the title and subtitle of the work, chapter headings, preface, notes, etc. belong - that is, that in some sense we can find "inside" the text. Epitext is more correlated with the "external" in relation to the text: an interview with the author, advertisements, reviews by critics, etc. Paratext is thus composed of a peritext and an epitext. In his book, G. Genette analyzes in detail various types of the publishing peritext, the meaning of the author's name (or lack thereof) on the cover of the work, the role, types and functions of headings, epigraphs, initiations, notes, the value of supercovers, as well as public and private epithexes. Paratextuality was also presented in the classification of G. Genette in the book "Palimsestes: La litterature au second degree". Paratextuality completes the text and transforms it into a product that is already in the hands of the reader. It is believed to be a special zone between text and non-textual reality, which is intended for the direct impact on the reader [10].

Paratext elements take a strong position in the text, since they are separated from the main text and communicatively completed. In the terminology of N.Kuzmina, such elements are "extremely powerful energy signs," in which the presence of the author is always noticeable and thanks to which the author implicitly broadcasts meaningful information for him. An important function of paratextual elements is informative. As a rule, paratexts introduce some information about the text following them: they set the theme of the work, outline the leitmotifs of individual parts, reveal the concept of the work, update the semantic dominant of the text, or enter some subtext information, while indicating the author's attitude to it. Paratext is a mask behind which the author hides, when he, not wanting to speak directly, indirectly determines his attitude to the events depicted by him in the work. In addition, he is able to set the form, language, stylistic structure of the subsequent work. So, paratextual elements, "on the one hand, reveal the author's intention, on the other hand, form the reader's presuppo- 
sition, create pragmatic conditions for understanding the text as a metatext" [4, p. 151]. According to this concept, there is a division of the text into two levels: deep and superficial. At the same time, the deep level has the character of coding meaning and is represented by such logical-semantic concepts as an invariant, a semantic core, a central link and a semantic node. The surface layer decodes the elements of the deep level with the help of variable expansion, background, periphery and context. The functional semantic dependence, by means of which the content of the speech situation is selected in the microthematic, thematic, macrothematic and textological plans, combines the elements of the deep and superficial levels, creating the text as a decoded unit of written speech [4].

As it is well-known, the title of the work has a huge potential, which persuades the reader need to familiarize with it. That is why contemporary writers are turning the title into an effective tool for pragmatic influence. In a pragmatic aspect the most important for the title is its informative and emotional content. The pragmatics of the title is usually motivated by the following factors: authocentricity - that is, reflection of the author's outlook, intentions, desires), anthropocentricity (focusing on the reader, taking into account his/her aesthetic and cultural preferences and background knowledge), prospectivity (connection with the consequent text). The title is interpreted as a relatively independent functional, structural, and semantic unit that can exist separately from the main body of the text and, at the same time, interpret the theme and idea of the work. L. Sakharnyy considers the name of the literary work as a special category of texts - primitive ones, which are a kind of convolution of an artistic text, which subsequently reveals all the inner potential of the name [3, p. 221].

\section{The autograph paratext of $S$. King}

As the material for the study we have chosen the works of Stephen King and their translations. His publications include over sixty novels (including seven under the pen name Richard Bachman) and six non-fiction books, more than two hundred stories included into nine author's collections. The name "Stephen King" has undoubtedly become a "mark of quality". So, picking up a book that is authored by Stephen King, the reader understands that it is a detective, horror story or a thriller. Moreover, it is a work of the "highest grade": interesting, fascinating, and stylistically literate - worthy 
of attention and reading. In this case, the name of the writer itself is a good advertisement that does not need any applications. Perhaps it is from this that the author's surname is printed in large capital letters on the cover of the book. Thus, without even looking in details at the cover of the book, the reader immediately sees the famous name, which is associated even for an inexperienced reader with a great literary work. Although the design of the book cover refers to the allographic (publishing) paratext, in this case the main role is played by the name of the author, which is one of the components of the autograph (author) paratext.

Despite the fact that scientists divide the paratext into author's and publishing's paratext and say that they have different goals and objectives, we believe that when in the book cover design these two types of paratextuality work in tandem to attract the reader's attention to this work. They are closely related as the font of the name of the author and its location of the book cover are chosen by the publisher. In this case, we can see that the publisher is "betting" on the well-known name of the author of the work, focusing on the attention of the reader.

\section{The title as a basic paratextual element}

The interpretation of the compositional structure of an artistic text has traditionally begun with its name. The title of the work forms an image of the result of the text, and the titles of the sections, being a textual supplement, are intended to help the reader to identify the meanings that are within his intentional structure. The reader retrospectively comprehends the title in relation to the whole text, as the title in full, or in a modified form participates in the semantic organization of the text.

Until recently, as a rule, the communicative function of the title of a literary work, as an element of a dialogue between the author and the reader, has not been the subject of a special research concerning its marginality with respect to the text of a work of art.

The theme of the work and the titles of the chapters of a literary work bear the material expression of the composition and the language structure of the work. So, our task is to see their functional workload, which will bring us closer to an adequate interpretation of the literary work. The theme is one of the key categories of poetics because it identifies a literary work, names it, presents it to the reader and, at the same time, "expresses the basic 
idea, a concept of the creator of the text" [1, p. 133]. As it is figuratively pointed out, "having absorbed in its insignificant volume the whole artistic world, the title has a tremendous energy of a tightly rolled spring" [6]. The disclosure of this convolution is purely individual in nature, and it begins with the expectation of familiarity with the text, with the formation of the installation for reading this work, from a period that can be called pretext. Thus, the title of the work conveys in a concentrated form its main theme and idea, which determines its connection with the whole text, as well as the possibility of realizing the meaning of the title in full only in its retrospective form, in reading, after the implementation of all lines of communication "the Title - the Text". In this case, the actualization of the lexical-semantic variant of the title word, the uniqueness of the semantically-casual phrase is possible only on the basis of the whole text. Accordingly, the title of the work of art serves as a symbol in the text. The title symbolism is formed throughout the text as a whole. The semantic specificity of the header in this case is that it concludes both the concretization and the generalization of the meaning. The first is due to the attachment to a particular situation, and the generalization, the next concretization, is associated with the inclusion in the decipherment of the title of multiple meaningful elements of the artistic text, which allow the title to become a sign of something typical, generalizing [6].

The title reflects the author's vision of reproducible situations, realizes the author's intention as a whole. The autocentricity of the headline can be implicit and explicit. In the latter case, the title contains a direct author's score, which expresses his position on future events.

In this case, self-centeredness involves the subjective assessment of the writer of the main characters, such as: Apt Puрil (Здібний учень), Ваd Little Kid (Поганий хлопчисько), Big Driver (Великий водій), Blockade Billy (Блокада Біллі), The Dark Man (Темна людина), He is Legend (Він легенда), The Man Who Loved Flowers (Людина яка любила квіти), The Man Who Would Not Shake Hands (Чоловік, що не тиснув руку), Man With a Belly (Людина з животом), Mister Yammy (Містер Красунчик), Mostly Old Men (Переважно старі люди), The Old Dude's Ticker (Ходики старого чувака), The Outsider (Aутсайдер), Paranoid (Параноїк), The Sun Dog (Сонячний пес), The Ten O'clock People (Люди десятої години), Thinner (Худнучий). D. Wunderlich calls these pragmatic types of headings 
representative, they express affirmations, explanations, statements, definitions and are intended to inform and identify [15].

The title can convey the author's vision of the events portrayed, such as: A Good Marriage (Гарний шлюб), Desperation (Biдчай), Elevation (Піднесення), Everything's Eventual (Все можливо), Golden Years (Золоті роки), America With Three Chords and an Attitude (Америка з трьома акордами та ставленням), Prетіuт Hагтопу (Гармонія nреміум), Shining in the Dark (Сяйво у темряві), Shock Rock (Шок Рок), Strawberry Spring (Сунична весна), Transgressions (Провини), The Weird (Дивний), What's Scary (Що страшне). The implicit authocentricity lies here not only in the direct author's assessment of events or characters, but in the formation of the author's image.

As we know, the task of the title of a literary work is to attract the reader's attention, to hint at the main object of the work. An important role here is played by the background knowledge of the reader, which sometimes focuses on the title of the work. To this end, modern writers use terminological or borrowed vocabulary in the headlines, which is a marker of their intellectual level. For example let's take the following names of S. King's works: The Nightmare in the Sky: Gargoyles and Grotesques (Kошмар y небі: Гаргульї та Гротески) - a Gargoyle is a stone-cut extended sculptural figure in the form of a head of fantastic beasts, monsters, men etc., in the Middle Ages it was a characteristic element of Romanesque and Gothic architecture; The word "grotesque" usually means "weird, fantastic, eccentric, or ugly," and thus is often used to describe ancient or distorted forms, such as Halloween masks or gargoyles on cathedrals. The title Turning the Thumbscrews on the Reader (Iспанський чобim) also presumes that the audience is acquainted with medieval methods of torture. The thumbscrew is an instrument of torture for crushing the thumbs used during the Spanish Inquisition. We should mention that in the Ukrainian translation the name of another but much more well-known torture instrument is used (the bootikin) in order to raise the attractiveness of the title.

Thus, the author assumes that the reader has some certain knowledge on the terminology related to the world of art and ancient architecture. As for usage of borrowed words, we can see them in the following titles: $\underline{\text { Obits }}$ (Oбітс) is a shortening for Latin "Obituaries" (Latin "obitus" - "death") - Некрологи; New Terror Omnibus (Збірка Нових Жахів) - we should 
mention that "omnibus" (French) is not just a collection of literary works, but also this word in Latin means "all", so we have a play on words - "New horrors for all"(«Нові жахи всім»), the heading Danse Macambre (French for "Танок смерті") verbalizes the terminological concept of the Dancing Death in the History of the Art - a widespread story in Western European culture, originally in mottoes and literature, later in frescoes, paintings and series of engravings from the 14 th to the 20 th centuries, as well as in music and theater.

In addition to the pragmatic aim to build the author's own image, the mentioned headlines attract the attention of the reader. The anthropocentricity of the headline is supposed to make contact with the reader and to influence the recipient. The headlines are directly addressed to the addressee and can model the situation of the author's dialogue with the reader. In order to fulfill the attractive function of the title, the authors also use such a stylistic technique as the "intimation" of the story, when the effect of the presence of a real interlocutor is created, live communication is simulated and the contact is established. All methods of the creation of this contact with the reader are combined with the help of a phatic function. Among such titles we have recorded erotetive titles, which are expressed with interrogative constructions, for example: Ever Et Raw Meat? (Колись їли сире м'яco?); directive titles, which express request, orders, requirements, such as Stand Ву Ме (Залишся зі мною), Turn Down the Lights (Погаси світло), Fear Itself (Бійся), Head Down (Вклони голову), Never Look Behind You (Ніколи не Оглядайся); vocative titles, that verbalize appeals, calls, such as: Sorry, Right Number"(Вибачте, вірний номер), Zombies! Zombies! Zombies! (Зомбі! Зомбі! Зомбі!). The last example contains ordinary repetition which gives the title some expressiveness and emotionality. The emotions of the author are also manifested at the level of syntax - namely, in the exclamation structure, which is one of the means of realization the phatic function implementation.

\section{Character titles}

Among the names of literary works the so-called character titles are usually distinguished. The title's focus on the recipient is most explicitly expressed in the names that include the character's name, focusing the reader's attention on the main character of the story. As it is well-known, 
a proper name can function as an important source of information in the title. In addition to the semantic, the noun can carry some contextual information, which is additionally imposed on the message, style, associative, etc. That is, the proper name in the title is multifunctional. The obligatory onym's language functions - nominative, identifying, differentiating - are layered by many others, thus allowing the use of proper names in headings for illustrative purposes [2]. So, anthroponyms implicitly or explicitly characterize the subject or object that will be described in the literary work. By structure, we have distinguished a number of options:

1) The first and the last name of the protagonist. For example: Dolores Claiborne (Долорес Клейборн), Holly Gibnеу (Холлі Гібні).

2) Character's last name. For example: Mr. Mercedes (Micmep Мерседес), Slade (Слейд), Blaze (Блейз).

3) Character's first name. In this case, as in the previous two options, the proper name becomes a nickname; it becomes a symbol of some phenomenon, problem or quality. For example: Aуапа (Аяна), Carrie (Kерi), Chinga (Чінга), Christine (Крістіна), For Owen (Овену), Nопа (Нона), Misery (Мізері), Willa (Вілла), Сијо (Куджо), Lauri (Лорі), Тотmу (Томмі), Diпо (Діно).

4) The first name or (and) the surname with the attribute, the object which belongs to him or her, or a sign that should make the character closer to the reader, tell about his or her, or its age, status, etc. For example: Charlie the Choо-Сhоо(Чарлі Чу-чу), Blockade Billy (Біллі Блокада), Blind Willie (Сліпий Віллі), Uncle Otto’s Truck (Вантажівка Дядька Oтто), Gwendy's Button Box (Шкатулка Гвенді), Dolan's Cadillac (Каділак Долана), Rose Madder (Роза Марена), Donovan `s Brain (Мозок Донована), Uncle Clayton (Дядько Клейтон).

5) The first name or (and) the surname and some motive of the life or events and actions of the character. Such titles usually imply the dynamics of the work. For example: The Dark Tower: The Song of Susannah (Темна вежа: Пісня Сюзанни), The Death of Jack Hamilton (Смерть Джека Гамільтона), Gerald's Game (Гра Джеральда), Harvey's Dream (Сон Гарвi), Herman Wouk is Still Alive (Герман Вук ще живии), L.T.'s Theory of Pets (Теорія домашніх тварин: Постулат Л.T.), The Girl Who Loved Tom Gordon (Дівчина, яка любила Тома 
Гордона), The Lonesome Death of Jordy Verrill (Одинока смерть Джорді Верілла), Mrs. Todd's Shortcut (Короткий шлях Miccic Toдд), The Revelations of Becka Paulson (Вiдкриттл Бекі Полсон), Uтпеу's Last Case (Остання справа Амні), The Return of Timmy Butterman (Повернення Тіммі Батермана), Coffey's Hands (Руки Коффi), The Bad Death of Eduard Delacroix (Погана смерть Делакруа), Harvey`s Dream (Сон Гарві).

6) The combination of the name with the designation of the genre. For example: The Chronicles of Harris Burdick (Хроніки Гаріса Бурдіка), The Diary of Ellen Rimbauer (Щоденник Еллен Рімбо), Lisey's Story (Iсторія Jiзi), The Tale of Gray Dick (Iсторія Діка Грея).

A significant factor in enhancing the meaning and emotional content of the title itself and the text as a whole is the sound form of the proper name used in the title of the work. An unusual or especially organized combination of sounds causes a specific auditory response, which becomes a source of pleasure or dissatisfaction. Although the response to the sounding of the name is undoubtedly subjective, the psychometry of many acts of perception allows us to average and objectify individual impressions, that is, to anticipate the audience's response to the use of "made" onyms in the title [2]. The names of fantasy creatures that have been invented by S. King and used as titles of his works and later included in modern dictionaries and have synonymous equivalents, include: The Tommyknockers (Томінокери) (actually, a Tommyknocker is an American variant and a Tocker is a Welsh variant of the Irish Leprechaun, but S. King's creatures have nothing in common with this folklore character) [12; 13], The Reploids (Реплоїи) ("reploid" is a portmanteau word on the basis of words "replica" and "android") and The Langoliers (Лангол'єри) ("langolier" is a synonym for a chronophage).

There distinguished similar headlines that indicate the main character's social or professional status, such as: The Gunslinger (Стрілок), The Library Policeтап (Бібліотечний поліщейський), Big Driver (Громіла. Прямий переклад - Великий водій), Doctor Sleep (Доктор Сон), Jитрer (Пригун), The Lawnmower Man (Газонокосар), Milkman (Молочник), The Night Flier (Той, хто літає вночи), The Regulators (Регулятори), The Secretary of Dreams (Секретар снів), The Turbulence Expert (Експерт з турбулентності). 


\section{The headers denoting time and place of action}

In the structure of nominative sentences functioning as titles, S. King often uses geographical names, real or belonging to the fictional worlds of the writer. In this case the sentence headers have a dual function: attributive and circumstantial, clearly and accurately naming the venue: American Vampire (Американський вампір), Brooklyn August (Серпень у Брукліні), The Colorado Kid (Хлопець з Колорадо), Harrison State Park (Гарісон Стейт Парк), Strange Maine (Дивний Мейн), Hearts in Atlantis (Серия в Атлантиді), Battle of Jericho Hill (Битва на Iєрихонському Xолмі), Wolves of the Calla (Вовки Kaльі), The Battle of Tull (Taльська Битва), The House on Maple Street (Дім на Кленовій вулииі), Little Sisters of Eluria (Смиренні сестри Eлyрiï), Lunch at the Gotham Café (Сніданок в кафе Готем), Why We Are in Vietnam (Чому ми у В 'єтнамi?).

Often titles that indicate the place of action can not only model the space of the artistic world, but also introduce the main symbol of the work. For example: Castle Rock (Касл-Рок), Crouch End (Крауч Енд), Jerusalem's Lot (Доля Салему), Duта Кеу (Острів Дума), The Dark Tower (Темна вежа), Aиtopsy Roот Four (Секиійний зал номер чотири). In addition to direct names of location, S. King often uses indirect, descriptive titles that brings some mystery to the perception of the work, intrigues the reader. For example: Joyland (Джойленд (прямий переклад Земля радості)), The Way Station (Проміжна станція), Under the Doте (Під куполом), A Very Tight Place (Під замком), In the Tall Grass (У високій траві), Battleground (Поле битви), Beachworld (Пляж), In the Deathroom (У кімнаті смерті), Rest Stop (Зупинка), Pet Sematary (Кладовище домашніх улюблениів), The Dead Zone (Мертва зона), The Waste Land (Безплідні землі), Music Room (Музикальна кімната), The Bone Church (Церква з кісток).

In the course of analyzing the paratextual elements in S. King's works, we have also found headings denoting time and space. With all the conventionality of the "new reality" created by the author, the basis of the fictional world, as well as the real world, is a chronotope which coordinates - time and place - are often indicated in the titles of works. In addition to the cyclic coordinates (names of time of day, days of the week, months), the time of action may be indicated by a date which is correlated with a historical event, for example: 11/22/63 (22 Листопада 1963 року) (November 22, 63 
is the date of the assassination of the USA President John Kennedy). Not only the "points" on the temporal axis but also the entire "segments" that mark the chronological frames of the story can be indicated in the title of the literary work. At the same time, the author, focusing the reader on a certain period of time - sometimes it is only one day or even some part of the day - seeks to convey both the essence of being and the "clot of life" of his characters, emphasizes the typical nature of the events described [6]. For example: Four Past Midnight (Четверта година після півночі), Three Past Midnight (Третя година після півночі), Straight Up Midnight (Прямо опівночі), One Past Midnight (Одна година після півночі), Strawberry Spring (Сунична весна), 1922, The night of the Tiger (Ніч Тигра), The Ten O'Clock People (Люди 10ї години ранку), Graduation Afternoon (Після випускного), The Music Room (Музикальна кімната), The Hotel at the End of the Road (Готель у кіниі дороги), The Rock and Roll Dead Zопе (Мертва зона Рок-н-Рол).

The particular importance in the dialogue of the author with the reader is the stylistic characteristics of the title, which provide the title with clarity and informativeness. In this case, involvement of sociolects, slang words and other non-literary elements into the title has a clear pragmatic orientation: to orient the addressee in the following socio-cultural space of the work, for example: "Ever Et Raw Meat? And Other Weird Questions" (Чu Їли Колись Сире М'ясо? Та Інші Чудернацькі Питання) - in this case, the translator did not misspell the word "ate", which in the original text is a part of an elliptical sentence that imitates live, spoken language; Great Hookers I Have Known"((Як Підчепити Читача)) - although the word "hooker" has the translation of "prostitute", drunkard", "alcoholic", the translator into Ukrainian used a softened, though colloquial, variant "pick up". The names Popsy (Дiдусь), The Old Dude's Ticker (Ходики Старого Чувака) ("ticker" in this text is a slang equivalent not for "the clock" but for "the heart"), Gramma (Бабуля) also contain a spoken vocabulary.

\section{The title intertextuality}

In order to set the reader to a certain course of events in a text authors also use intertextuality in the title, thus linking a new story with already known realities of culture. This connection is established through the submission of straightforward and transformative quotes and the involvement 
of literary characters. As we know, allusion is an important type of nomination and is very effective in strong positions - the title and the epigraph. The pragmatic content of allusive titles is revealed retrospectively after reading the literary works. The importance of the title information is determined by its ability to reveal the meaningful plan of the whole work. At the same time, the general background knowledge of the writer and readers is relevant, based on which the author deliberately influences the recipient through the purposeful selection of language units for titles. For example, in the following title the words from a popular song are used in order to draw attention to the text: Heavenly shades of night are falling (Тіні ночі спускаються з небес) - is the first line from The Platters' "Twilight Time" song. In the story Five to One, One in Five (П'ять до одного, один в п'яти), the title words that come from Jim Morrison's song and the Doors band become a sinister element in the plot. This phrase, which performs a prognostic pragmatic function, implies the events of the work: Five to one, baby, one in Five, No one here gets out alive now. So, the reader with some background knowledge can already build a certain logical chain about the plot of the work and foresee how exactly events will unfold.

The use of the well-known proper names in the title brings to life those potentialities which enhance the expressiveness of the titles of the literary works. For example, the headline Cain Rose Up (Каїн повстав) appeals to the Bible, the title Batman and Robin Have An Altercation (Бетмен та Робін сперечаються) refers to the famous book of comics and superhero movie series, The Gingerbread Girl (Імбирна дівчина) hints at the scary fairy tale of brothers Grimm about Gretel and Hansel, the New Tales of Cthulhu Mythos collection (Нові міфи Ктулху) almost duplicates the title of a famous work about Cthulhu of a horror classic writer H.P.Lovecraft, "The Call of Cthulhu". The Reaper's Image (Відображення Смерті) is an allusion to the Grim Reaper - "Sorrowful Reaper"- as Death is often portrayed in European (and, in particular, Ukrainian) culture as a skeleton with a scythe, dressed in a black sweatshirt with a hood. In the novel Rita Hayworth and Shawshank Redemption (Рита Гейворд та втеча з Шоушенку) the writer uses the name of a famous Hollywood actress of the 1940s, a poster with the image of which helped the protagonist to escape from prison.

Toponyms included into the titles of works also perform the same function. For example, Hearts in Atlantis (Серия в Атлантидi): the name of a 
fictitious country hints at the mystery of the events of the work. According to the plot, the main character Riley compares the era of his youth to Atlantis, which disappeared into the depths of the sea and will no longer return. Names of mythological, historical, literary characters, denoting such concepts, which stand out for their definiteness, durability and popularity, are stable lexical units with significant suggestive and associative capacity. For example, in addition to the aforementioned work called American Vampire, in the works of S. King we also see: American Vaтріге (Американський вамnip), Cycle of the Werewolf (Цикл перевертня), The Boogeyman (Бука), The Demons (Демони), Johnathan and the Witches (Джонатан ma Biдbми),The Eyes of the Dragon (Очі дракона), The Leprechaun (Лепрекон). As we can see, these titles contain tokens that denote mythological creatures that are well-known in Western culture, which makes the headlines particularly attractive, interesting for a reader, because they create an atmosphere of a fairy tale.

Similarly function the following headings:

I Am the Doorway (Я - дверi) - the statement "I am the door", contained in John's Gospel, 10: 7, and is the third of the seven statements "I am" of Jesus. These "I AM" proclamations indicate his unique, divine identity and purpose. In this statement, "I AM", Jesus clearly points to the exceptional nature of salvation. In Stephen King's work, this phrase has a more direct meaning, because the main character considers himself a door to alien invasions and horrific murders.

The title Flight or Fright (Тікай або Бійся) is a paraphrase, a hint of the well-known medical term "Fight or Flight", which stands for "physiological changes in the body (such as increased heart rate or bronchial enlargement) in response to stress" [9].

The title of the storybook, which includes works by S. King and his son Joe Hill He Is Legend (Він - Легенда), is an adaptation of Richard Matheson's book "I am a Legend" (1954) to which this anthology was devoted. "Here Be Tygers" (Тут можуть бути тигри), is the name of the title of the novel written by American writer Ray Bradbury, published in 1951. It is thought that this phrase comes from the ancient times of the first geographical findings, when maps of uncharted areas often contained Latin phrases like "Hic sunt leones" ("here may be lions"), so the word "tygers" is written in English in archaic form. The name of the story Well and Pendulum 
(Колодязь та Маятник) also duplicates the title of another work. This is a direct allusion to the work of the father of horror literature Edgar Poe with the same title.

The title If Thy Right Hand Offend Thee, Cut It Off (Коли правиия твоя спокушає тебе, відсічи іii) is a direct quote from Matthew 5:30. Another name-phrase - In the Tall Grass (У високій травi), comes from the sports jargon. This collocation means scoring the ball outside the golf field, which causes difficulties for the player. The expression is used figuratively, because the protagonists do not play golf but are in a difficult position. The heading One Drop of Blood (Одна крапля крові) is an allusion to the "One drop rule." It is an unofficial household and cultural setting that existed until the mid-20th century, especially in the US, and consisted in the strict observance of the theory of "purity of race", according to which a person with the smallest percentage of "Negro blood" should be considered "black" in all respects [14]. The name Monster in the Closet (Монстр y maqi) refers to the English idiom "skeleton in the closet", used to describe secret shameful facts about someone, but in this literary work a true "skeleton" (monster) appears in a real closet. The idiomatic title One for the Road (На посошок) appears in the story in its main meaning - the last drink before going home ("Let's have one for the road," says Tookie. - It's time to close"), but in the course of the story this phrase takes on a more specific meaning - one, alone on the road, on the way, as the main characters meet vampires on a deserted road and are forced to fight them all alone. Phraseological units are also used in the headings Deep Water (У тихому вирі) - it is a part of the idiom "deep waters run deep", Under Weather (Хвора) and Bag of Вопеs (Мімок з кістками). It is remarkable that the former phrase is used in the denotative meaning of its components as the story isn't connected with anybody skinny or "extremely thin" but with real bones, remnants of victims in a bag.

So, with the help of idioms and the play of words (the pun) the author has created original, attractive headlines that are well-remembered and catch the attention of the reader. In another story with the name Sleeping Beauties (Сплячі красуні) women go to sleep in a sticky white cocoon, we see a hint on the famous Charles Perrault's tale "Sleeping Beauty". According to the plot, when women fall asleep, they find themselves in a different, better place where harmony reigns, and conflicts are extremely rare, but if 
the shell covering their heads gets damaged or broken and wakes them up, they become wild and incredibly violent.

Thus, as we can see from the examples given above, such a technique of quoting or allusion is very productive; it is used for compression and promotes the function of influence. In addition to the message function, the title of the literary discourse also implements the function of influence, which manifests itself in expressiveness, imagery, emotionality and evaluation. The presence of a "text-to-text" sharpens the dialogicality of the discourse, increases the moment of a play, serves as a subtext [5]. The pragmatic impact of these headlines is in updating the reader with his or her prior knowledge of the titles of works and names borrowed by the writer to create a certain extralinguistic context for the perception of the further content of the novel or story.

Clear but at the same time strange titles for the reader often reflect the author's desire for epithet and intrigue, for example: Drunken Fireworks (П'яні феєрверки), I Was a Teenage Grave Robber (Я був підлітком, що грабував могили), The Word Processor of the Gods (Комn'ютер богів), The Little Green God of Agony (Маленький зелений бог агоніï), Riding the Bullet (Вверхи на кулі), The Road Virus Heads North (Дорожній вірус прямує на північ), That Bus Is Another World (Цей автобус ие іншій cвim), They're Creeping Up Оп Үои (Вони повзуть на тебе). For this very purpose abbreviations, capitalization, additional "non-letter" symbols are included in the title of the works, for example: 11/22/63, 1408, The $43^{\text {rd }}$ Dream (43й сон), 1922, From a Buick 8 (3 Б'юіку 8), N (H), Mile 81 (Миля 81), GUNS (ГАРМАTИ), SCREEM (КРИК), Shadows 4 (Тіні 4), UR(УP). Squad D (Загін Д), The Dreaded X (Страшний Iкс), IT (ВОНО).

The title's perspective makes it possible to harmonize the artistic text with its artistic world (main characters, time and space, etc.). The condensed headline reflects the main theme, outlines the major storyline, or indicates a major conflict. For example, the title of a piece by P. Straub and S. King The Talisman (Талісман) performs an informative function (telling the reader of the main problem of the novel and the protagonist's purpose - to get a Talisman to save his mother) and an integrative function by combining plot lines.

The title can determine the genre of a story, causing the reader to associate it with a particular type of literary work, such as: The Ballad of 
the Flexible Bullet (Балада про гнучку пулю), Big Wheels: A Tale of the Laundry Game (Великі колеса: Казка про гру в пральні), The Chronicles of Harris Burdick (Хроніки Гаріса Бурдіка), The Diary of Ellen Rimbauеr (Щоденник Еллен Рімбо), The Tale of Gray Dick (Казка Сірого Діка), Tales From the Darkside (Казки з темної сторони), Tales of Unknown Horror (Казки про невідомий жах), Tales of the Dead (Казки мертвих).

The anthropocentricity and forward-looking nature of the title cause the reader to interpret it correctly create a waiting effect for the recipient that may or may not be justified after reading the text. According to Z. Turaeva, only the fully semanticized title contributes to the successful readers' perception of the work [7, p. 56]. Thus, not only the titles that contain the names and characteristics of the main characters are considered to be correct from the point of view of prognostication, but also those that outline the main issues. In such cases, non-extended and extended nominative one-member sentences are actively used in the headers, which carry out the nominative function - name the text containing the pivot word of the text. For example: Afterlife (Життя після смерті), The Aftermath (Наслідки), The Body (Tpyn), The Cannibals (Канібали), Cell (Сотовий), The Crate (Ящик), Creepshow (Шоу жахів), Desperation (Bìчай), Dreamcatcher (Ловець снів), Firestarter (Та, що породжує вогонь), Graтmа (Бабуля), IT (Воно), Insomnia (Безсоння), The Jaunt (Весела подорож), Magicats (Чудокоти), Mercy (Мерсі. Direct translation - Милосердя), The Mist (Туман), The Monkey (Maвna), Nightmares (Нічні жахи), The Outsider (Чужинеиь), The Raft (Пліт), Rage (Лють), The Reach (Протока), The Ring (Кільце), Roadwork (Дорожні роботи), Shadows (Тіні), The Shining (Сяйво), Shivers (Тремтіння), Sleepwalkers (Ti, хто ходять уві cнi), Sneakers (Кросівки), The Stand (Onip), The Talisman (Талісман), Terrors (Страхи), Transgressions (Грiхи), The Ledge (Карниз), Throttle (Горлянка), Trucks (Вантажівки), The Weapon (Зброя), Weeds (Бур'яни).

Frequency of the usage of such types of titles can obviously be explained by their informative brevity, limited content capacity, and therefore the ability to attract the reader's attention, his or her curiosity. Predictably controversial are the polysemantic titles that make associations unambiguous in the reader's mind and predict the content of the play. These are headlines like: Rose Madder (Роза Марена). "Madder" stands for "the madder staining plant". The plant's English name is in tune with the word "mad" - "crazy". 
The use of abstract nouns in the headings enhances their ambiguity and increases the degree of generalization, resulting in the appearance of similar, homonymous names, and reduces their attractiveness, for example: Revival (Відродження), Dedication (Присвячення), Mетоry (Пам'ять), Morality (Мораль), A Death (Смерть), Silence (Tиша). However, the author relies on his name, which is popular worldwide, and considers it sufficient to convince the reader of the correct choice of a fascinating work. Unwarranted prediction can create rating headlines when the meaning of the text is the opposite of the meaning of the tokens used in the title. For example, the semantics of the title A Good Marriage (Щасливий илюб) sets the reader to a positive perception and appreciation of the life of the heroine of the work. However, the story convinces another: her husband turned out to be a maniac murderer and the woman had to kill him herself. Some headings have an ambivalent pragmatic direction: on the one hand, they are able to make the reader interested in reading and further decoding the title; on the other, they may be alienating and then readers are unwilling to find explanations for the semantics of the title in the text. For example: The Two Dead Girls (Дві мертві дівчинки). Thus, the writer often takes risks of the audience attention, but the horror genre involves a certain readership, and what may alienate a common reader may, on the contrary, interest the horror lover.

\section{Conclusions}

The most important paratextual element of the composition of Stephen King's literary works is the title which plays the important structural and substantive role, since it sets the perspective of an ideological and semantic interpretation of the work. The analysis revealed that the titles are extremely important in the artistic system of a book, since they are the exact semantic projection of the ideological and artistic content of the corresponding discourse and act as a kind of connection between the reader and the author of the text. Headings in Stephen King's works are not just phrases prefaced to the entire text or parts of it. They are one of the artistic means of creating meaningful completeness. Directing the reader with a title to a particular set of events, the writer creates an internal subtext that prepares for the perception of the book. Artistically conditioned and significant titles can also be considered as allusions, hints to the idea of the story, to the turning points of the plot, to the main characters. 


\section{References:}

1. Ghak, V.Gh. (2006). Praghmatyka, uzus y ghrammatyka rechy [Pragmatics, Usage and Grammar of Speech]. Ynostrannye jazyky v shkole, 8: 111. (in Russian)

2. Kovalevsjka, T.Ju. (2001). Semantyka onimnykh asociatyviv u reklamnomu dyskursi [The semantics of onymous associations in advertising discourse]. Opera in Onomastica, 5: 3-11. (in Russian)

3. Kubrjakova E.S., ShakhnarovychA.M., Sakharnyj,L.V.(1991)Chelovecheskyj faktor v jazyke. Jazyk y porozhdenye rechy. Moscow: Nauka. (in Russian)

4. Kuzmina, N.A. (2004). Intertekst $i$ yego rol' v protsessakh evolyutsii poeticheskogo yazyka [Intertext and its role in processes of evolution of poetic language]. Moscow: Yeditorial URSS. (in Russian)

5. Lotman, Ju.M. (2016). Kuljtura y vzryv [Culture and Explosion]. Moscow: ACT. (in Russian)

6. Tokarjeva, T. (2010). Do problemy ponjattja tekstu i roli zagholovka tekstu jak jogho orghanizujuchogho elementu [The problem of the concept of text and the role of the title of the text as its organizing element]. Naukovi zapysky [Kirovoghradsjkogho derzhavnogho pedaghoghichnogho universytetu imeni Volodymyra Vynnychenka]. Ser. : Filologhichni nauky, 89 (5): 62-67. (in Ukrainian)

7. Turayeva, Z.Y. (2012). Lingvistika teksta [Text linguistics]. Moscow: Librokom. (in Russian)

8. The Complete library of Stephen King works (n. d.). Retrieved from: https://www.stephenking.com/the library.html (accessed 21 October 2019).

9. Fight or flight. (n. d.). In Merriam Webster. Retrieved from: https://www. merriam-webster.com/dictionary/fight-or-flight (accessed 21 October 2019).

10. Genette, G. (1982). Palimsestes: La litterature au second degree. Paris: Éditions du Seuil.

11. Genette, G. (1997). Paratexts: Thresholds of Interpretation. Cambridge: Cambridge University Press.

12. McIntyre, E. (2014, September 1). The Faeries of the Cornish Tin Mines - Cousin Jack and the TommyKnockers. Transceltic. Retrieved from: https://www.transceltic.com/cornish/faeries-of-cornish-tin-mines-cousin-jack-andtommyknockers (accessed 21 October 2019).

13. Nokker. (n. d.). In Icy Sedgwick. Retrieved from: http://www.icysedgwick. com/knockers (accessed 21 October 2019).

14. Wright, L. (1994, July 17) One Drop of Blood. The New Yorker. Retrieved from: https://www.newyorker.com/magazine/1994/07/25/one-drop-ofblood (accessed 21 October 2019).

15. Wunderlich, D. (1976). Studien zur Sprechakttheorie. Frankfurt am Main: Suhrkamp. 